\title{
5 The Periphrastic Subjunctive in the Old English Multiple Glosses to the Lindisfarne Gospels
}

\author{
Marcelle Cole \\ Utrecht University
}

The recessive nature of the subjunctive as a formal category in Old English is witnessed in the use of alternative grammatical structures other than inflectional subjunctives in contexts of non-fact modality. An increasing analytic reliance on grammatical devices signalling nonfact modality (e.g. gif 'if', sua hua 'whoever', etc.) both fostered and facilitated the occurrence of the indicative in such contexts. The modal verbs magan, "sculan and willan served as fully independent verbs in Old English, but even during the Old English period there appears to have been a 'modern' tendency to use modal constructions involving a (subjunctive) modal + infinitive construction, instead of an inflectional subjunctive, with little (or no) underlying sense of non-modal notional meaning. ${ }^{\mathrm{I}}$

In the Old Northumbrian (ONbr) interlinear gloss to the Latin text of the Lindisfarne Gospels (British Library, MS Cotton Nero D.iv; henceforth $\mathrm{Li}$ ), the increasing lack of direct correspondence between contexts of non-fact modality and the subjunctive in Old English is attested in the widespread tendency for present-indicative forms in $-s$ and -ð to supplant subjunctive forms, e.g. 7 swiðe bebead him patte hia ne awades $t$ mersades hine $\mathrm{L}$ et uehementer comminabatur eis ne manifestarent illum 'And he very much commanded them that they should not make him known' MkGl (Li) 3.I2, or for indicative forms to alternate with subjunctive forms, which in ONbr ended in $-a /-e /-o$ in both

${ }^{1}$ For detailed discussion of the semantics of the Old English modal verbs see Standop (I957: I8-66, 94-I32, I33-I 55), Visser (I963-I973, iii \I483, \I562, \1653), Mitchell (I985, $\mathbb{S}$ IOI2-IOI 5, $\mathbb{S}$ IOI9-IO2O, $\mathbb{S}$ IO2I-IO22), and the dictionaries.

How to cite this book chapter:

Cole, M. 20I5. The Periphrastic Subjunctive in the Old English Multiple Glosses to the Lindisfarne Gospels. In: Shaw, P., Erman, B., Melchers, G. and Sundkvist, P. (eds) From Clerks to Corpora: essays on the English language yesterday and today. Pp. 7I-8 5. Stockholm: Stockholm University Press. DOI: http://dx.doi.org/IO.I6993/bab.e License: CC-BY. 
the singular and plural, e.g. gif gie habbas thoebbe leafo L si habueritis fidem 'If you have faith' MtGl (Li) 21.2I and poette gie eta 7 drincga [...] 7 gie sittað ofer heh sedlo L ut edatis et bibatis [...] et sedeatis super thronos 'That you may eat and drink [...] and sit on high thrones' LkGl (Li) 22.30 (see Cole, 20I 4 for extended discussion). ${ }^{2}$ Periphrastic modal verb + infinitive constructions also occur in $L i$ to translate the Latin subjunctive mood, as in 7 sohton ða hehsacerdas 7 ða uðuuto buu bine mið facne gehealdon 1 moebton hia gehalda 7 ofslogon $t$ hia moebton of slaa $\mathrm{L}$ et quaerebant summi sacerdotes et scribae quomodo eum dolo tenerent et occiderent 'and the chief priests and the scribes sought how they might with wile lay hold of him and they might kill him' MkGl (Li) I 4.OI. ${ }^{3}$ The glossator's reliance on structures other than the inflectional subjunctive is possibly all the more surprising given the requirements of the glossing process to render the Latin as atomistically and faithfully as possible in the target language.

The present paper examines the glossator's use of the modal + infinitive construction in $\mathrm{Li}$ in relation to that of the inflectional subjunctive and indicative simple verb forms. The strategy of using modal + infinitive structures in the translation of Latin subjunctives in $\mathrm{Li}$ has long been noted (Bosworth \& Toller I 898, magan), yet data drawn from the ONbr glosses are not included in any of the major studies on Old English modal verbs (cf. Gorrell I 895; Standop 1957; Ogawa I989). Modal + infinitive constructions in $L i$ occur frequently (though not exclusively) in multiple glosses whereby a single Latin lemma is rendered using at least two Old English glosses, separated by Latin vel 'or' (abbreviated to $t$ in the manuscript). Multiple glosses conveniently facilitate the comparison of the forms that occur in identical contexts of non-fact modality in ONbr. Certain properties of the multiple glosses

2 The abbreviations used in this paper to refer to the Lindisfarne Gospels (Li) and the West Saxon Gospels (WSCp) are those employed by the Dictionary of Old English Web Corpus (DOEC) and identify gospel, chapter and verse. The DOEC relies on Skeat's (I87I-I887) edition of the Gospels. Citations are taken from the DOEC, checked against the online facsimile of $L i$ available at $<$ http://www.bl.uk/ manuscripts/FullDisplay.aspx?ref=Cotton_MS_Nero_D_IV>. Biblical translations translate the Old English text as opposed to the Latin and are my own. Multiple glosses in the Old English text are provided with one Modern English translation.

3 Northern variants of $u t o n+$ infinitive also occur in $L i$ to translate the Latin hortative subjunctive, e.g. gæ we $t$ wutum geonga L eamus 'Let's go!' but this usage will not be dealt with in this paper. 
may also function as a diagnostic for evaluating the status of modal + infinitive constructions in Old English.

\section{The periphrastic subjunctive in Old English}

The extent to which modal + infinitive constructions functioned interchangeably with inflectional forms as periphrastic expressions of mood is a vexed question that has received a great deal of attention in the literature (Gorrell I895; Standop I957; Krzyszpién I980; Mitchell I98 5; Goossens 1987; Ogawa 1989). The need for caution in too readily interpreting modal verbs as grammatical circumlocutions for the inflectional subjunctive has been reiterated in the literature: modal verbs often present little loss of primary meaning and occur in the subjunctive under the same circumstances that trigger its use with other verbs (Mitchell I985, $\mathbb{S}$ 297I-2980). The terms 'modal' and 'modal auxiliary' are in themselves problematic, given that these verbs functioned as independent lexical items in Old English and the issue of whether magan, "sculan and willan expressed mood at this early stage is controversial. I follow Mitchell ( 1985 , \$99I) in using the label 'modal auxiliary' for want of a better term, but in full awareness of the potential prolepsis involved in employing the terms 'modal' and 'auxiliary' with regard to the function of these verbs in Old English.

From a historical point of view, it has been argued that in the initial (Old English) stage of the history of the subjunctive and the 'modal auxiliaries' in English, modal verbs with an infinitive were treated as grammatical equivalents to inflectional subjunctive forms (Gorrell I 895). The growing tendency in the language to use auxiliary constructions was triggered and propagated by the breakdown in the formal distinction between the indicative and subjunctive inflectional forms of verbs. Gorrell's examination of the frequency of Old English 'modal auxiliaries' in relation to that of inflectional subjunctives in indirect discourse indicates a striking increase in the use of the periphrastic construction with a distinct tendency to occur when the corresponding inflectional forms of verbs would prove ambiguous (I 895: 458).

Observations in the literature that the use of a periphrastic subjunctive was fostered by the breakdown in the formal distinction between the indicative and subjunctive mood is particularly pertinent to the ONbr gloss. One of the main characteristics of the ONbr texts is the advanced state of morphological simplification across the verbal system caused by various processes of reduction and levelling, including the proliferation 
of the northern present-tense marker $-s$ at the expense of - $\partial$, and the early loss of final $-n$, most notably in the infinitive and present-plural subjunctive, but also in the preterite-present plural verbs and preterite indicative and subjunctive (see Cole 20I4). The preterite subjunctive and indicative are more often than not indistinguishable from each other as the preterite plural subjunctive shows preterite-indicative -on endings rather than -en and indicative forms occur with subjunctive -en, which suggests the coalescence of the endings in [-ən].

The view of the history of the modal auxiliaries as a simple chronological development whereby modal + infinitive constructions increasingly occur as a subjunctive equivalent as the Old English period progresses is belied, however, by the textual variation that the incidence of modal verbs exhibits in the Old English period. Ogawa's (1989) survey of Old English texts indicates a varying incidence in the use of the periphrastic construction across different text types and time periods that challenges what he terms the 'substitution theory', the notion of the history of the English subjunctive as characterised by the use of modal auxiliaries to compensate for the loss of inflectional morphology. His analysis of the meanings of the modal verbs in subjunctive contexts does not show the degree of loss of semantic meaning which would be expected if the verbs were being used as auxiliaries. Instead modal verbs are employed to convey a particular shade of meaning as required by the context: their use adds a nuance that is not explicit in the inflectional subjunctive. The suggestion that the periphrastic construction is not a mere grammatical alternative to the inflectional subjunctive but expresses instead a semantic nuance not found in the simple subjunctive is in line with Standop (I957: I69) and Krzyszpién (I980). The latter argues that periphrastic magan + infinitive and the inflectional subjunctive were not wholly semantically interchangeable. The use of one form or the other was determined by a difference in meaning: inflectional subjunctives denoted general non-fact modality whereas the periphrastic magan + infinitive expressed a particular aspect of non-fact modality, objective possibility. When magan itself occurred in the subjunctive inflectional form "general non-fact modality was 'superimposed' on the narrower meaning of objective possibility" (Krzyszpién, I980: 5I).

Ogawa's findings, in particular, emphasise the relevance of text type and stylistic factors in determining the occurrence of the modal verbs; there is a preference for poetry as opposed to prose to favour the use of modal verbs across the entire Old English period, probably as a stylistic poetic device that added emphatic detail (Ogawa I989: 23 I-232; 
Gorrell I 895: 458). In prose, modal verbs are favoured in argumentative religious and philosophical writings and homiletic literature rather than in narrative prose. Text type and subject matter are also found to affect the individual incidence of each modal verb, e.g. magan and "sculan are common in didactic and religious writings where the latter commonly serves to emphasise commands, whereas narrative prose works show a preference for willan (Ogawa I989: 235). Interestingly, the West Saxon Gospels (Corpus Christi College Cambridge MS, I4O; henceforth WSCp) exhibit an "almost entire neglect of the periphrastic [modal] forms" (Gorrell I 895: 458). The low incidence of modal verbs in WSCp is attributed by both authors to the translator holding "slavishly" to the Latin original (Gorrell I 895: 458; see also Ogawa I989: 225, 236). Verse translations in the Paris Psalter and the Kentish Psalm reflect a similar reluctance to employ periphrastic forms (Ogawa I989: 236), which tells in favour of a close degree of dependence on the Latin source inhibiting the use of periphrastic [modal] forms. The avoidance of periphrastic forms involving modal verbs found in WSCp does not, however, find a parallel in the interlinear ONbr glosses in $L i$; despite the glossarial nature of the text type, the glossator's language is not as subjugated to the demands of atomistic glossing as might be expected. ${ }^{4}$

\section{Modal + infinitive and the subjunctive mood in $\mathbf{L i}$}

$L i$ is consistent with general Old English usage in its employment of the modal + infinitive compound instead of an inflectional subjunctive form of the verb in indirect discourse after verbs of thinking and believing and in the employment of willan with expressions of promise (Gorrell I 895: 449-455), exemplified in ( $\mathrm{ra}$ ) and ( $\mathrm{Ib}$ ), respectively. Such usage overlaps broadly with the future-in-the-past employment of

${ }^{4}$ It should be borne in mind, nevertheless, that neither the Old English translation in WSCp nor $L i$ is consistent in its attitude towards the Latin original. The effect of Latin influence is at times blatantly obvious in $L i$; for instance, the Latin negative imperative construction nolite (plural) / noli (singular) + infinitive is categorically translated using a contracted negative form of the verb willan followed by an infinitive in an attempt, no doubt, to render the Latin construction as atomistically as possible, e.g. nallaðgie g[e]wyrce L nolite facere 'make not!' JnGl (Li) 2.I6 and nolle gie gedoema L nolite iudicare 'judge not!' JnGl (Li) 7.24. Contrastively, the continuous prose translation in WSCp diverges from the Latin in its rendering of negative imperatives and follows a more native $\mathrm{OE} n e+\mathrm{V}+$ Spro structure compared with the literal counterparts found in $\mathrm{Li}$, as in ne wyrce ge Jn (WSCp) 2.I 6 or ne deme ge Jn (WSCp) 7.24. 
the preterite subjunctive (Mitchell I985: \$646) found in (Ic). It should be noted that ( $\mathrm{Id}$ ) is the only instance in which "sculan is used periphrastically to translate a Latin subjunctive in $L i$ (Kotake 2006: 44). Ogawa's (1989: 235) observation that "sculan commonly serves to emphasise commands would seem to find exemplification here. ${ }^{5}$

(I)a. wiste forðon buoelce noere seðe salde bine t ualde hine sealla 'for he knew which one it was who would betray him' sciebat enim quisnam esset qui traderet eum

JnGl (Li) I3.I I

b. ðona $t$ forðon mið að gehatend wœes hir pet sealla walde suce hucet woelde giwiga $t$ giviade from him

'therefore with an oath it was promised to her that he would give whatsoever she would ask of him'

unde cum iuramento pollicitus est ei dare quodcumque postulasset $a b$ eo

MtGl (Li) I 4.7

c. 7 forhuon ne saldes ðu feh meh to wege $t$ to disc 7 ic miððy cuome mið agnettum $t$ untedlice ic giude t walde ginge pot 'and why did you not give my money to the bank, and when I came, with usury indeed I would have exacted it?'

et quare non dedisti pecuniam meam ad mensam et ego ueniens cum usuris utique exigissem illud

LkGl (Li) I9.23

d. 7 buu auritten is on sunu monnes pette feolo geðolas $t$ scile ðoliga 7 gehened $t$ geniðrad $t$ geteled

'and how it is written about the Son of man that he must suffer many things and be despised'

5 *sculan is more widely used in $L i$ to translate the Latin future tense where it approximates a modern periphrastic future on occasions, e.g. from hernise gie geheras 7 ne oncnougie $t$ ne cuðon ge 7 gesegende ge sciolon gesea $t$ ge geseas 7 ne geseað $t$ ne sciolon gesea $\mathrm{L}$ auditu audietis et non intelligitis et uidentes uidebitis et non uidebitis 'By hearing you shall hear, and shall not understand: and seeing you shall see, and shall not perceive’ MtGl (Li) I3.I4; in caelo geong sua huct ðu hobbe bebyg 7 sel ðorfendum 7 hofis $t$ ðu scealt habba gestrion in heofne $\mathrm{L}$ uade cumque habes uende et da pauperibus et habebis thesaurum 'Go, sell whatsoever you have and give to the poor and you shall have treasure in heaven' MkGl (Li) I0.2 I; 7 gie geseað $t$ scilon gesea sunu monnes to suiðrom sittende ðœs moehtes L et uidebitis filium hominis a dextris sedentem uirtutis 'And you shall see the Son of man sitting to the right of the power of God' MkGl (Li) I4.62 
et quomodo scribtum est in filium hominis ut multa patiatur et contempnatur

$\mathrm{MkGl}(\mathrm{Li})$ 9.I 2

The construction magan + infinitive is used in $L i$ in both the present and preterite in clauses of purpose, a usage that is not peculiar to $L i$, but which differentiates it from WSCp where magan is never used in purpose clauses: there is a preference for willan instead (Ogawa I 989: 236). In the case of (2a) and (2b), the inflectional subjunctive gesii alternates with (subjunctive) magan + infinitive. Behre (I934: 92 , fn. I) states that the subjunctive form of magan + infinitive is the only way of unambiguously expressing subjunctive mood in the first-person singular given the lack of formal distinction between the first-person present-indicative and subjunctive. In ONbr gesii is a subjunctive form (Ross I937: I33), which effectively eliminates morphological ambiguity as a motive for including moge + infinitive alongside gesii in the double gloss. Standop (I957: 60-6I) suggests that magan expresses a different kind of uncertainty from the subjunctive of a simple verb. Similarly, as previously mentioned, Krzyszpién (I980: 5I) argues that subjunctive magan + infinitive is not a mere circumlocution for the subjunctive but contributes semantic precision by expressing a particular aspect of non-fact modality, that of objective possibility. The inclusion in $L i$ of both an inflectional subjunctive and moge + infinitive would seem to corroborate this view. Behre's hypothesis may hold nonetheless in preterite contexts where the simple verb form is formally indicative but indistinguishable from the subjunctive in speech (example 2c).

(2)a. huced wilt ðи ðе pot ic gedoe se blinde untedlice сиоеð him larun god poette ic gesii $t$ pot ic moge sea

'what (do) you want that I do to you? The blind man indeed said to him: master, that I may see'

quid uis tibi faciam caecus autem dixit ei rabboni ut uideam

MkGl (Li) I0.5 I

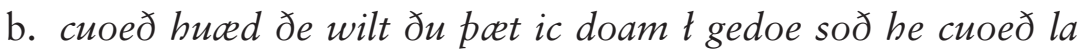
dribten potte ic gesii t gesea moge

'he said: what (do) you want that I do to you? Indeed he said: Lord, that I may see'

dicens quid tibi uis faciam at ille dixit domine ut uideam

LkGl (Li) I 8.4 I 
c. monigo forðon he gehcelde ðus pæette hia raesdon on him patte bine hie gebrindon $t$ hrina moebtoes

'for he healed many, thus that they pressed upon him that they might touch him'

multos enim sanabat ita ut inruerent in eum ut illum tangerent

$\mathrm{MkGl}(\mathrm{Li}) 3 . \mathrm{IO}$

Clauses of indefiniteness involving sede and sua hua, sua buelc 'whoever', sucehucelc 'whatever', etc. generally required a subjunctive verb form in Old English, although the indicative became increasingly common as the period progressed (Visser I963-1973, i. \$886). Indicative and inflectional subjunctive forms both occur in indefinite contexts in $L i$, e.g. in suabuelcum hus gie inngae L et in quamcumque domum intraueritis 'in whatever house you enter' LkGl (Li) 9.4; on sua huelcne hus gie ingæeə $\mathrm{L}$ in quamcumque domum intraneritis 'in whatever house you enter' LkGl (Li) I0.5. There is also one instance of a double gloss consisting of both an inflectional subjunctive and an indicative, e.g. sua buelc iuer hobbe $t$ hæefed friond $\mathrm{L}$ quis uestrum habebit amicum 'whoever of you has a friend' LkGl (Li) I I.5. The Li glossator also avails himself of a further strategy in double glosses and renders the Latin subjunctive using a (subjunctive) modal + infinitive construction. In double glosses present indicative $t$ welle + infinitive is the particular combination of grammatical forms that is employed in $L i$ to translate the Latin subjunctive mood in clauses of indefiniteness. This strategy is illustrated in $(3):^{6}$

(3)a. seðe soðlice ðerhwunes t ðerhwunia wella wið t in ende ðes hal bið

'he that truly perseveres until the end, he will be saved' qui autem persenerauerit in finem hic saluus erit

MtGl (Li) I0.22

b. 7 sua hua dringe selles $t$ sealla węlle anum of lytlum ðassum coelc $t$ scenc woetres caldes [...] ne loseð meard his

'and whosoever gives drink to one of these little ones a cup of cold water [...] he loses his reward'

quicumque potum dederit uni ex minimis istis calicem aquae frigide [...] non perdet mercedem suam

MtGl (Li) I0.42

6 See $\mathrm{Ib}$ in the present paper for the same combination of grammatical forms used in a multiple gloss in an indefinite clause, but in the preterite: suce hucet wolde giwiga $t$ giviade. The occurrence of unambiguous indicative forms in the present tense, illustrated in (3), suggests that giviade, though formally indistinguishable from the subjunctive preterite, was intended as an indicative form. 
c. 7 sua hua cueðes $t$ cиeða wele word wið sunu monnes forgefen bið him

'and whosoever speaks a word against the Son of man, it shall be forgiven him'

et quicumque dixerit uerbum contra filium hominis remittetur $e i$

MtGl (Li) I 2.32

d. 7 seðе suळe hucelc walla suerige $t$ seðe suerias on wigbed noht is seðe sua huelc untedlice walla sueria in gefo pat is ofer ð๙et is rebtlic

'and whosoever swears on the altar, it is nothing; indeed whosoever swears by the gift that is on it is a debtor'

et quicumque iuranerit in altari nibil est quicumque autem iuranerit in dono quod est super illud debet

MtGl (Li) 23.I 8

e. 7 cuoeð to him sua hwolc forletas $t$ forleta welle wif his 7 oðer laede derneleger efnesende $t$ geendade ofer hia $t$ bi hir 'and he said to them: whosoever puts away his wife and marries another, commits adultery against her'

et dicit illis quicumque dimiserit uxorem suam et aliam duxerit adulterium committit super eam

MkGl (Li) IO.I I

f. seðe welle losige tloses $t$ fordoes $t$ forforas sawel his fore meh onfindes hia $t$ ða ilco

'he that loses his life for me, shall find it'

qui perdiderit animam suam propter me inueniet eam

Mt (Li) I0.39

In double glosses, therefore, there is a preference for the modal periphrastic construction, as opposed to an inflectional subjunctive, to occur alongside a present-indicative form in clauses of indefiniteness. Clearly, both forms were acceptable grammatical alternatives in this context, although it should be noted that the subjunctive modal form welle is used and willan here retains an implied element of volition, intention or acquiescence. Given that the indicative also occurs in this context, the use of welle + infinitive may be an attempt to vivify the sense of modality inherent in clauses of indefiniteness as to the person, place, time referred to in the clause. The modal's primary meaning has not been eliminated, but such usage provides an insight into an intermediate stage in the development of the English periphrastic subjunctive. 
The apodosis of a hypothetical condition in ModE requires a preterite modal: in fact its occurrence in this environment serves as a test of modal status (Denison I993: 3 I3). In Old English the preterite inflectional subjunctive generally occurred in this context, e rally 'if God were your father indeed you loved me' Jn (WSCp) 8.47, where lufedon, though formally preterite indicative, is to be understood as a subjunctive. In $L i$, however, preterite forms of willan + infinitive occur in the apodosis of a hypothetical proposition, compare, gif god faeder iuer woere gie nalde lufiga untedlice mec 'if God were your Father, you would indeed love me' L si deus pater uester esset diligeretis utique me Jn (Li) 8.42. Visser (I963-I973, \I532, \I607, \I672) records such usage in Old English with should and might, but cites no examples of would for Old English, apparently dating the emergence of would in the apodosis of a hypothetical proposition to the early ME period. Instances of wolde in the apodosis of a conditional would appear to exist in Old English, however: Ogawa (I989: I3 I) identifies an example of wolde used with an inanimate subject in Elfric's Lives of Saints ( $E L S 3 \mathrm{I} .672$ ) that "may well serve as a pure expression of an imaginary event in the past". The examples in (4) illustrate the occurrence of walde in the apodosis of a hypothetical condition in $\mathrm{Li}$.

(4)a. gif nere ðes yfeldoend ne ðe ue gesaldon $t$ nalde ue gesealla bine ðe

'if he were not this evildoer, we would not have delivered him up to you'

'si non esset hic malefactor non tibi tradidissemus eum

JnGl (Li) I 8.30

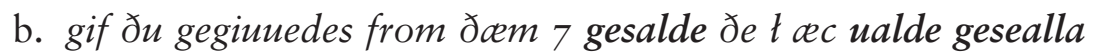
ðe uxeter cuic llifwelle uxter

'if you had asked of him, and he would have given you living water'

petisses ab eo et dedisset tibi aquam uiuam

JnGl (Li) 4.IO

Here willan serves to express an intermediate idea between simple volition and an imaginary past result: it cannot be said that walde is entirely non-volitional in nature, but it does approximate 'modern' usage in conveying the probable past results of an unreal past condition. The examples also succinctly exemplify the lack of formal opposition between the indicative and the subjunctive in the preterite that may well have contributed to the glossator's decision to signal non-fact modality more explicitly using a periphrastic form. 
As previously noted, periphrastic subjunctives occur frequently in double glosses in $L i$, which, given the preference for multiple glosses in $L i$ is not in itself significant. ${ }^{7}$ Nonetheless, the double-glossing translation technique provides a unique insight into what type of grammatical units co-occurred in identical contexts. Multiple glosses in Li generally involve two items, though triple and even quadruple glosses also occur (see examples $\mathrm{Id}$ and $3 \mathrm{f}$ in the present paper, in which the triple glosses gehened $t$ genidrad $t$ geteled and loses $t$ fordoes $t$ forforas translate Latin contempnatur 'scorn, despise' [3sg pres.subj.pass.] and perdiderit 'lose, destroy' [3sg perf.subj.act.], respectively). The multiple glosses vary with regard to the type of information that they supply; some provide lexical alternatives for a single Latin lemma, involving the use of synonyms or near-synonyms, e.g. berað t bringeð L adferte 'bring!' JnGl (Li) 2I.Io. Other double glosses provide grammatical alternatives for a single Latin lemma, e.g. geseað 1 geseas L uideritis 'you see' LkGl (Li) 2I.20, ne habbas $t$ nabbas L non habent 'they do not have' MtGl (Li) I4.I6, or supply both a grammatical and a lexical alternative, e.g. goe we t wutu [m] geonga L eamus 'Let's go!' MkGl (Li) I. 38 .

In double glosses translating the subjunctive mood the preferred strategy in $L i$ is to juxtapose an indicative with a (subjunctive) modal + infinitive, rather than an inflectional subjunctive. It would be an oversimplification to infer that the occurrence of the periphrastic construction alongside simple forms in double glosses is in itself proof that the modal + infinitive structure is a mechanical substitute for the inflectional subjunctive. Double glosses in $L i$ clearly provide alternatives that are equally acceptable in a given context but they convey differing nuances. Double lexical glosses generally involve an item that introduces a semantic nuance, such as berað $\dashv$ bringeð L adferte 'bring!' JnGl (Li) 2I.IO, cited above, or a contextualised nuance. Pons-Sanz (forthc.) cites the rendering of L puella as dohter tmoegden at MkGl (Li) 5.4 I. The Latin lemma puella would normally be translated using OE moegden 'girl, maiden', but here, Pons-Sanz argues, OE dohtor 'daughter' is included because the girl referred to is the daughter of the leader of the synagogue mentioned a few lines previously. Even alternative grammatical glosses, such as gesead $t$ geseas $\mathrm{L}$ uideritis $\mathrm{LkGl}$ (Li) $2 \mathrm{I} .20$ and ne habbas $t$ nabbas $\mathrm{L}$ non habent $\mathrm{MtGl}$ (Li) I4.I6, which appear to present simply morphological variants, provide an additional form that is more idiomatic or colloquial, such as the dialectal ONbr second-person plural form geseas

7 Kotake (2006: 37, fn. 4) gives the total occurrences of multiple glosses in $L i$ at 3 I 59, of which 466 are grammatical glosses. 
alongside geseað 'you see' at LkGl (Li) 21.20, or nabbas instead of ne habbas at MtGl (Li) I4.I6. Similarly, the double glosses under scrutiny involving 'modal auxiliary' constructions are a complex case that do not necessarily involve grammatically interchangeable forms with no difference in meaning. Careful analysis suggests that the periphrastic modal subjunctive is a grammatically acceptable - if somewhat stylistically different - alternative to the inflectional subjunctive.

With regard to the ordering of the items in double grammatical glosses in $L i$, i.e. whether the glossator chooses to place a term in first or second position, Kotake (2006) identifies a considerably consistent pattern in the ordering of the alternative grammatical glosses, including those that translate Latin verbs forms conveying future tense and subjunctive mood. In the majority of cases, the double glosses consist of a simple form in first position followed by a periphrastic construction. He attributes this ordering preference to the glossator placing the Old English grammatical category that is morphologically closest to the Latin first, followed by the "more morphologically marked" periphrastic construction (2006: 44-46). I interpret the grammatical unit that most deviates from the Latin original as the more idiomatic or colloquial item in the doublet. The translation technique of double glossing provides the glossator with the scope to include one Old English translation that is atomistic and closely parallels the Latin morphologically and another that distances itself from the original Latin text and provides a more concrete or colloquial rendering. Such an interpretation both corroborates and finds support in Ogawa's contention that the modal verb phrase probably reflects colloquial Old English usage. Ogawa notes the tendency for modal verbs to occur more readily at the colloquial rather than literary level of Old English prose and in direct speech and suggests that "the colloquial level of style favours the use of modal verbs in its endeavour to make description vivid and concrete" (I989: 237-238). The colloquial sphere of usage is also a locus of grammatical change where the 'modern' periphrastic future and subjunctive forms would be expected to make their first appearance.

\section{Summary}

The data in $L i$ provide further insight into an intermediate stage in the history of the periphrastic subjunctive whereby modal verbs were used initially to emphasise a particular aspect of non-fact modality that an inflectional subjunctive could only do more generally and which indic- 
ative forms left unexpressed. The notion of the history of the English subjunctive as characterised by the use of modal auxiliaries to compensate for the loss of inflectional morphology only tells part of the story of the English periphrastic subjunctive: stylistic factors were of considerable importance. In a succinct summary of the Old English state of affairs, Ogawa (I989. 223-234) highlights that the varying distribution of modal verbs across text types

points to no clear tendency for them to form the 'periphrastic subjunctive' when the corresponding simple verb form would be ambiguous with respect to mood. [...] Although the distinction between the modal verb construction and the simple verb form is not always easy to explain, the former can be generally shown to stand for clearer, more concrete expressions, emphasizing and specifying, by the appropriate choice of a relevant modal verb, a particular nuance of desired relationship as the context requires it

The status of the modal verb construction as a clearer, more concrete expression that emphasises and specifies is also in line with the double glossing technique found in $\mathrm{Li}$. Double grammatical glosses generally provide one translation that is morphologically closer to the Latin and an additional gloss that is more idiomatic or colloquial, in this case, the modal verb construction.

Nevertheless, the type of grammatical structures that alternate in double glosses alongside modal verb constructions also suggest that the breakdown in formal opposition between the indicative and subjunctive played a role in the history of the subjunctive and the 'modal auxiliaries' in English. Double glosses such as poette ic gesii $t$ poet ic moge sea $\mathrm{L}$ ut uideam $\mathrm{MkGl}$ (Li) I0.5 I indicate that moege sea is not a mechanical grammatical circumlocution for the subjunctive form gesii. But in cases such as ne ðe ue gesaldon $t$ nalde ue gesealla $\mathrm{L}$ tradidissemus $\mathrm{JnGl}(\mathrm{Li})$ I 8.30 , the lack of formal opposition between the indicative and the subjunctive in the preterite may well have fostered the use of the periphrastic structure as a more distinctive means of signalling non-fact modality; after all, walde + infinitive is the only way of unambiguously expressing non-fact modality given the coalescence of the preterite indicative and subjunctive. It is also important to bear in mind that even in the present where unambiguous subjunctive forms were retained for longer, modal + infinitive constructions co-occur mainly with indicative forms in double glosses rather than the inflectional subjunctive. The lack of direct correspondence between contexts of 
non-fact modality and the subjunctive (inflectional or periphrastic) in Old English and the increasing occurrence of present-indicative (or of morphologically ambiguous preterite) forms would also have fostered the use of periphrastic subjunctive forms. The glossator's preferred strategy in $L i$ of juxtaposing an indicative with a (subjunctive) modal + infinitive, rather than an inflectional subjunctive militates in favour of Krzyszpién's (1980: 62) view that one of the functions of modal verb compounds was to serve as "a more distinctive and productive means of signalling non-fact modality" [be it a particular aspect of non-fact modality] left unexpressed by indicative forms.

\section{References}

Behre, F. (1934). The Subjunctive in Old English Poetry. (Göteborgs Högskolas Årsskrift 40). Göteborg: Elanders.

Bosworth, J., \& Toller, T.N. (I898). An Anglo-Saxon Dictionary Based on the Manuscript Collection of the Late Joseph Bosworth. Oxford: Oxford University Press.

Cole, M. (20I4). Verbal Morphosyntax in Old Northumbrian and the (Northern) Subject Rule. (NOWELE Supplement Series). Amsterdam \& Philadelphia: John Benjamins.

Denison, D. (1993). English Historical Syntax. London \& New York: Longman.

[DOEC =] Dictionary of Old English Web Corpus. (2007). Antonette diPaolo Healey et al. (eds) Toronto, ON: University of Toronto. <http://www.doe. utoronto.ca/pages/pub/web-corpus.html>.

Goossens, L. (1987). The auxiliarization of the English modals: a functional grammar view. In M. Harris \& P. Ramat (eds) Historical Development of Auxiliaries. Berlin \& New York: Mouton de Gruyter, I I I-I43.

Gorrell, J.H. (I 895). Indirect discourse in Anglo-Saxon. PMLAA, I0, 342-485.

Kotake, T. (2006). Aldred's multiple glosses: is the order significant? In M. Ogura (ed.), Textual and Contextual Studies in Medieval English: Towards the Reunion of Linguistics and Philology. Bern: Peter Lang, 35-5 I.

Krzyszpién, J. (1980). The periphrastic subjunctive with magan in Old English. Studia Anglica Posnanienia I I, 49-64.

Mitchell, B. (I985). Old English Syntax, 2 vols. Oxford: Clarendon.

Ogawa, H. (1989). Old English Modal Verbs: A Syntactical Study. (Anglistica, 26). Copenhagen: Rosenkilde \& Bagger. 
Pons-Sanz, S. (Forthcoming). A study of Aldred's multiple glosses to the Lindisfarne Gospels. In J. Fernández-Cuesta \& S.M. Pons-Sanz (eds) The Old English Glosses to the Lindisfarne Gospels: Language, Author and Context. Berlin: Mouton de Gruyter.

Ross, A.S.C. (I937). Studies in the accidence of the Lindisfarne Gospels. Leeds School of English Language Texts and Monographs 2, Kendal.

Skeat, W. W. (ed.) ( I 87 I-I 887). The Holy Gospels in Anglo-Saxon, Northumbrian, and Old Mercian versions. Cambridge: Cambridge University Press.

Standop, E. (1957). Syntax und Semantik des modalen Hilfsverben im Altenglischen: 'magan', 'motan', 'sculan', 'willan'. (Beiträge zur Englischen Philologie, 38 ). Pöppinghaus, Bochum-Langendreer.

Visser, F. T. (1963-1973). An Historical Syntax of the English Language, 3 parts, 4 vols. Leiden: E. J. Brill. 